\begin{tabular}{|l|l|c|c|}
\hline Eiszeitalter u. Gegenwart & 34 & $1-5$ & Hannover 1984 \\
\hline
\end{tabular}

\title{
A Volcanic Ash-Fall at the Early/Mid Weichselian-Würmian Transition in the Peat Bog of Grande Pile (Vosges, France)
}

\author{
Etienne Juvigne \& NiLs-Axel MörneR*)
}

\begin{abstract}
Volcanic ash-fall, lacustrine sediments, carotte, Early/Mid Weichselian transition, radiometric dating, pyroxene clino, peat bog.

South Vogesen, Grande Pile, Haut Rhin
\end{abstract}

\begin{abstract}
A continuous core of lacustrine sediments from the well-known Grande Pile locality in northeastern France was analysed. We report here on a new ash bed, the "diopside ash-fall"; its stratigraphic position at the Early/Mid-Weichselian-Würmian transition is quite firm. At present, radiometric dating does not not permit more precise dating of this ash bed than between $53,000-62,000$ B.P. In total 5 ash beds have been reported from the peat bog of Grande Pile.
\end{abstract}

\section{[Ein vulkanischer Aschen-Niederschlag an der Wende frühes / mittleres Weichsel - Würm im Torfmoor von Grand Pile (Vogesen, Frankreich)]}

Kurzfassung: An einem zusammenhängenden Bohrkern aus quartären Seesedimenten von Grande Pile (Süd-Vogesen, Frankreich) wurden petrographische Untersuchungen durchgeführt und dabei eine weitere tuffitische Lage entdeckt, die durch Klinopyroxene (wahrscheinlich Diopsid) charakterisiert ist. Diese wird an die Wende der Hauptkaltphase der frühen Weichsel zum mittleren Weichsel gestellt. Nach ${ }^{14} \mathrm{C}$-Datierungen liegt das Alter zwischen 53000 und 62000 B.P.. Bislang wurden 5 tuffitische Lagen aus der Lokalität Grande Pile nachgewiesen.

\section{Introduction}

In the last 7 years, several volcanic ash layers have been discovered in the southern part of the Vosges, France.

SERET discovered an ash layer of Alleröd age in the peat bog of Frère Joseph/Vosges and the following heavy mineral suite was described: $33 \%$ basaltic hornblende, $9 \%$ highly pleochroic augite, $9 \%$ euhedral zoned zircon, $5 \%$ sphene and $44 \%$ euhedral apatite. It is suggested that this ash was erupted in the Eifel (in FrENZEL 1978).

JUVIGNE $(1976,1977)$ described another heavy mineral suite for the ash layer of Frère Joseph: $58 \%$ basaltic hornblende, $29 \%$ clinopyroxene and $10 \%$ sphene (3\% unknown). Volcanic zircon, apatite, and biotite could not be distinguished from local non-volcanic material.

*) Addresses of authors: E. Juvigne, Chercheur Qualifié au F.N.R.S., Université de Liège Laboratoire de Géomorpologie et de Géologie du Quaternaire, Place du XX Août, 7- 4000 LiègeBelgique. - N.A. MÖRNER, Ass.-Prof., Geological Insititute, Stockholm University, S-10691 Stockholm, Sweden. 
JUVIGNE (1978) mentioned the occurrence of a volcanic heavy mineral suite similar to that of Frère Joseph in two other peat bogs: Etang du Boffy and Grande Pile core II (WoILLARD 1975). The ash-falls of Frère Joseph and Etang du Boffy were correlated with the "Laacher See-Tuff 5 final" of Alleröd age but the ash-fall of Grande Pile core II occurred at $520 \mathrm{~cm}$ depth within the "Arcy-Kesselt interstadial" after a pollen diagram of WoILLARD (1975).

MÖRNER $(1977,1979,1981)$, using X-ray analysis, described 2 other volcanic ash beds (Ash G and N) in a core (labelled B 963) which was taken in Grande Pile right beside core X of WOILLARD (1975):

- Ash G, $1023 \mathrm{~cm}$ depth, about 50,000 years B.P.

- Ash N, 18.00-18.10 cm depth, about 130,000 years B.P.

JUVIGNE \& BASTIN (1982) discovered another ash layer at $435 \mathrm{~cm}$ depth in a core which was also taken very close to locality Grand Pile core X. Based on pollen evidence this ashfall occurred during the Preboreal. A sample located at $462-465 \mathrm{~cm}$ below the surface at the same locality was dated at about 11,500 B.P. (MÖRNER 1981).

The ash layer lies $30 \mathrm{~cm}$ above this sample. The source vent was probably the Chaîne des Puys (Massif Central français). Designation "tuf des Vosges méridionales" was given to this ash-fall.

\section{Research}

Core B 963 of MÖRNER $(1979,1981)$ was investigated. This core was taken with the Swedish foil piston corer in two continuous segments $(455-1194 \mathrm{~cm}$ and $1195-1846 \mathrm{~cm}$ depth). The 455-1194 cm section was microscopically analyzed by one of us (JUVIGNE). The lower segment of this core was not available because it was kept for additional paleomagnetic analysis.

\subsection{Method}

The core was previously cut in $3 \mathrm{~cm}$-segments for paleomagnetic studies (MÖRNER 1979). A quarter of each segment (about $5 \mathrm{~cm}^{3}$ ) was treated as follows:

- Boil with $\mathrm{H}_{2} \mathrm{O}_{2} 50 \mathrm{~V}$.

- Boil with $\mathrm{HCl}+\mathrm{HNO}_{3}$ (about $10 \%$ ).

- Wet-sieve through screens $420 \mathrm{~m} \mu$ and $63 \mathrm{~m} \mu$.

- Dry fraction 63-420 $\mathrm{m} \mu$ in oven.

- Separate in bromoform $(\mathrm{d}=2,89)$ using a centrifuge.

- Mount heavy minerals in Canada balsam.

- Look for volcanic minerals in the slides.

\subsection{Results}

A few clinopyroxenes (less than 10 grains) are present in most of the samples; these are light green and often show a parallel stria set terminated by acicular features (fig. 1a). Basaltic hornblende is rare. Both volcanic minerals are considered to be reworked from their source with non volcanic deposits. 
A
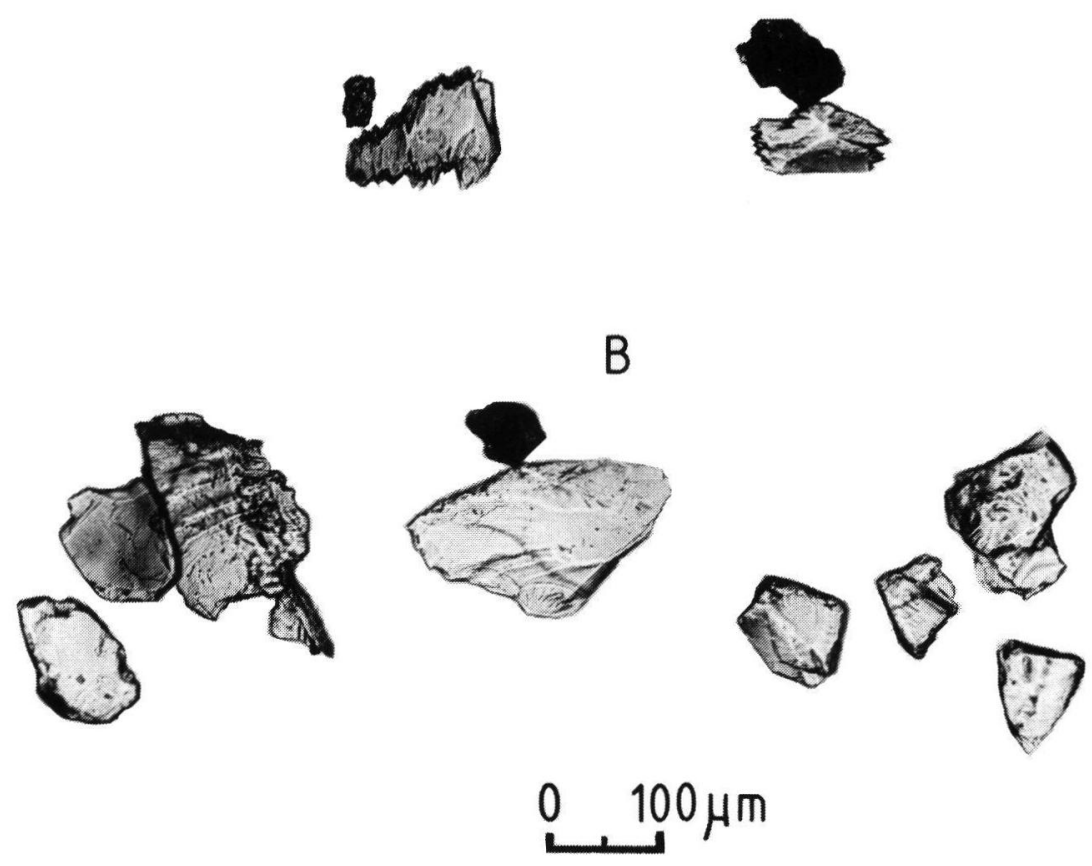

Fig. 1: Clinopyroxenes from grande Pile; (A) typical singular grains found in most of the samples, and (B) grains from the enriched horizon at the $1092-1095 \mathrm{~cm}$ depth.

The segment of $1092-1095 \mathrm{~cm}$ depth is greatly enriched in volcanic heavy minerals, although no significant change was visible in the core. In addition to 284 clinopyroxenes and 9 basaltic hornblendes, 528 biotites were found in the slide. Most of the biotite are believed to belong to the ash-fall because this abundance corresponds with a high enrichment of this mineral.

The clinopyroxenes are essentially colorless to pale green. Most of them are angular shards with no typical faces or cleavages (fig. 1b); a few of them are saw-edged. The coarsest grain was about $250 \mathrm{~m} \mu$ wide. These clinopyroxenes are suspected to be diopside. Because of previous use of different local terms for stratigraphical purpose (WOILLARD 1975), we propose to call this ash-fall "diopside ash-fall".

Stratigraphically, this ash lies just above the $5 \mathrm{~b}$ stadial of MöRnER $(1979,1981)$ which represents the maximum coldness of the Early Weichselian-Würmian Glaciation (Glaciation Maximum II of MÖRNER 1979). Hence it marks the transition between the Early and Mid-Weichselian-Würmian.

In absolute age, it seems to fall between 53,000 BP and 62,000 BP (MÖRNER 1979, 1981; WOILlARD \& MOOK 1982). 


\subsection{Search of Laacher See-Tuff in Grande Pile}

We remind in the former introduction the occurrence of Laacher See-Tuff in two other peat bogs in the vicinity of Grande Pile (Etang du Boffy and Frère Joseph).

In Grande Pile core II (WOILlARD 1975), JUVIGNE discovered an enrichment in volcanic material with a heavy mineral suite similar to that of the "Laacher See-Tuff 5 final". The designation "tuf de Grande Pile" was given. This enrichment was within the "ArcyKesselt interstadial", based on a pollen diagram of WOILLARD (1975).

Five different cores from the area near the Grande Pile core X have been investigated in order to find the "tuf de Grande Pile" and/or the "Laacher See-Tuff". This research met with no success but another ash layer was discovered (JUVIGNE \& BASTIN 1982).

Using mineralogical variations demonstrated by JUVIGNE \& SHIPLEY (1983) and JUVIGNE (1983) all these ash layers could be correlated with each other but this would be incompatible with the pollen diagrams.

\section{Conclusion}

In the Grande Pile peat bog five ash-falls have been discovered.

Three of them were recognized by their heavy mineral suites in the fine sand fraction:

- the "tuf des Vosges méridionales" of preboreal age (JUVIGNE \& BASTIN 1982).

- the "tuf de Grande Pile" of "Arcy-Kesselt interstadial" age (JUVIGNE 1978).

- the "diopside ash-fall" at the Early/Mid Weichselian-Würmian transition.

Two other volcanic layers have been discovered by X-Ray analysis; no specific volcanic heavy minerals were found in the fine sand fraction.

- Ash G about 50,000 years BP (MÖRNER 1979).

- Ash N about 130,000 years BP (MÖRNER 1979).

\section{Acknowledgment}

SUSAN SHIPLEY (University of Washington, Quaternary Research Center) is gratefully acknowledged for correcting our manuscript.

\section{References}

FRENZEL, B. (1978): Führer zur Exkursionstagung des IGCP-Projektes 73/1/24: "Quaternary Glaciations in the Northern hemisphere", 5. bis 13. September 1976, Südvogesen, nördliches Alpenvorland und Tirol. - Vervielfältigung: Deutsche Forschungsgemeinschaft, Bonn-Bad Godesberg.

Juvigne, E. (1976): Contribution à la connaissance de la stratigraphie du Quaternaire par l'étude des mineraux denses transparents de l'Eifel au Massif Central français et plus particulièrement en Belgique. - Thèse de doctorat en Sc. Géogr., inédit, Université de Liège, 235 p. - Liège.

- (1977): La zone de dispersion des poussières émises par une des dernières éruptions du volcan du Laacher See. 
Juvigne, E: Z. Geomorphol., 21: 323-342; Berlin, Stuttgart.

- (1982): Décoverte de mineraux volcaniques dans des tourbières des Vosges (France) - Bull. Soc. Geog. Liège, 14: 205-210; Liège.

- (1983): Les variations minéralogiques dans les retombées de 1982 du volcan El Chichón (Chiapas, Mexique) et leur intérêt pour la téphrostratigraphie. - Ann. Soc. Géol. Belg., 106, Liège. - [Sous presse].

- \& BAstin, B. (1982): Découverte d'un tuf volcanique d'âge préboréal à la Grande Pile (Vosges, France). - Bull. Soc. Géogr. Liège, 18: 31-40; Liège.

- \& ShIPLey, S. (1983): Distribution of minerals in the downwind tephra lobe of the May 18, 1980 eruption of the Mount Saint Helens (Washington, USA). - Eiszeitalter u. Gegenwart, 33: 1-7; Hannover.

MÖRNER, N.-A. (1977): Paleoclimatic correlations and chronology. - Proc., IX Congr. IUSPP (Nice 1976), H. de Lumley (Ed.), last resting volume.

- (1979): The Grande Pile paleomagnetic/paleoclimatic record and the European glacial history of the last 130,000 years. - Inter. Proj. Paleolimn. Late Cenozoic Clim., 2, 19-24.

- (1981): Weichselian chronostratigraphy and correlations. - Boreas. 10: 463-470; Uppsala.

Worllard, G. (1975): Recherches palynologiques sur le Pléistocène dans l'est de la Belgique et dans les Vosges lorraines. - Acta Geographica Lovaniensia, 14: 118p.; Louvain.

- \& MooK, W. (1982): Carbon-14 dates at Grande Pile: correlation of land and sea chronologies. - Science, 215: 159-161; London. 
Etienne Juvigné \& Nils-Axel Mörner 